\title{
THE 5E INQUIRY LEARNING MODEL: ITS EFFECT ON THE LEARNING OF ELECTRICITY AMONG MALAYSIAN STUDENTS
}

\author{
Eng Tek Ong ${ }^{1 *}$, Devi Govindasamy ${ }^{2}$, Charanjit Kaur Swaran Singh ${ }^{1}$, \\ Md Nasir Ibrahim ${ }^{1}$, Norwaliza Abdul Wahab ${ }^{1}$, Mohamad Termizi Borhan ${ }^{1}$, Siew Wei Tho ${ }^{1}$ \\ ${ }^{1}$ Universiti Pendidikan Sultan Idris, Malaysia \\ ${ }^{2}$ SK 2 Taman Selayang, Malaysia \\ *e-mail: ong.engtek@,fpm.upsi.edu.my
}

\begin{abstract}
The effectiveness of the 5E Inquiry Learning Model as compared to the teacher-centred traditional method on science achievement in electricity was examined in this study. The quasiexperimental pretest-posttest control group research design was utilized. A total of 65 students (33 and 32 students in the experimental and the control groups, respectively) from two Year 5 intact classes in Malaysia participated in this study. A test comprising 54 dichotomously scored items with overall KR20 reliability of .84 was used in the pretest and posttest. Given the significant difference in the pretest and posttest, it was presumed that the analysis could be done using the ANCOVA. However, on further analysis, the assumption for homogeneity of the regression slope was violated and ANCOVA could not be performed. Instead, the covariate was categorized into two equally-spaced categories (i.e., low and average achievers) and further t-test supported the equivalency of the experimental and control groups. When analyzed using the $t$-test, the two groups differed significantly in the posttest means across the two categories of students. These findings unequivocally indicate the effectiveness of employing the 5E Inquiry Learning Model in enhancing students' science achievement among the low and average achieving students.
\end{abstract}

\section{Keywords: inquiry learning, $5 E$, primary science, electricity.}

\section{INTRODUCTION}

In 1967, the 60:40 Science: Arts policy was announced and implemented by the Government of Malaysia given the great demand for science-based graduates. This 60:40 policy refers to the Malaysian Government's targets for $60 \%$ of all upper secondary students focus on the sciences to gain significant science content while the remainder $40 \%$ enrol in the arts (Ministry of Education, 2012). Therefore, to be considered as a science student, that student must enrol and study at least two pure science subjects among the Chemistry, Physics, and Biology at the Sijil Pelajaran Malaysia (SPM) level sat by 17-yearold students which are equivalent to the Grade $11^{\text {th }}$ students who followed through the General Certificate of Secondary Education (GCSE) in the United Kingdom.

Kamaludin (2019) opines that this 60:40 policy is a long-term plan towards realizing the aspired talented, highly-skilled, knowledgeable, competitive, and productive human capital. Additionally, Alcácer \& Cruz-Machado (2019) maintain that the need for these science and technology-based talents are meant to meet the demand of a digitalization era, while Vijaindren (2018) contends a crucial need for these talents capable of dealing with the demands of the Industrial Revolution 4.0 (IR 4.0). Despite the introduction and the implementation of the 60:40 policy, the science and technology-based upper secondary students' enrolment for the Year 2018 indicates that only $41.17 \%$ of the overall 361,980 students were enrolled in science, vocational and technical subjects (Ong, Luo, Yuan, \& Yingprayoon, 2020). This attained percentage still falls short of the aspired and targeted $60 \%$.

The failure to achieve the $60 \%$ of science and technology-based upper secondary students is further compounded by the humbled ranking of Malaysia at the international assessments, particularly in TIMSS, an acronym for the Trends in Mathematics and Science Study. Table 1 summarizes the trend in science achievement for Malaysia against the TIMSS $8^{\text {th }}$ Grade Scale or Centre Point over the past five cycles, namely in the years of 1999, 2003, 2007, 2011, and 2015.

As depicted in Table 1, Malaysia inaugurally participated in the TIMSS 1999 and TIMSS 2003, achieving the average scores 
Table 1. Trend in Science Achievement of Malaysia in TIMSS

\begin{tabular}{llllll}
\hline \multicolumn{5}{c}{ TIMSS (Science Achievement) } \\
\cline { 2 - 6 } & $\mathbf{1 9 9 9}$ & $\mathbf{2 0 0 3}$ & $\mathbf{2 0 0 7}$ & $\mathbf{2 0 1 1}$ & $\mathbf{2 0 1 5}$ \\
\hline Malaysia's average scale score & $492^{+}$ & $510^{*}$ & $471^{* *}$ & $426^{* *}$ & $471^{* *}$ \\
International standing & $22^{\text {nd }}$ & $20^{\text {th }}$ & $21^{\text {st }}$ & $32^{\text {nd }}$ & $24^{\text {th }}$ \\
& (out of 38) & (out of 45) & (out of 48) & (out of 63) & (out of 57) \\
\hline
\end{tabular}

Note: ${ }^{+}$no significant difference as compared to the international average; ${ }^{*}$ significantly higher as compared to the international average; ${ }^{* *}$ significantly lower as compared to the international average

of $492\left(22^{\text {nd }}\right.$ position $)$ and $510\left(20^{\text {th }}\right.$ position $)$ correspondingly. However, in TIMSS 2007, the average score plummeted to 471 ( $21^{\text {st }}$ position), and subsequently, in TIMSS 2011, the average score dipped further to that of 426 ( $32^{\text {nd }}$ position) (Martin, Mullis, Foy, \& Stanco, 2012). In TIMSS 2015 (Martin, Mullis, Goy, \& Hooper, 2016), the average score did improve to that of $471\left(24^{\text {th }}\right.$ position) although the average score achieved was still significantly below the International Average of 500.

The results of TIMSS are of great concern for the Malaysian Ministry of Education because the achievements in TIMSS are used as the benchmark for measuring the quality education as officially stated in the Malaysia Education Blueprint 2013-2025 (Ministry of Education, 2012), According to the benchmark, an aspired quality of education is achieved if and only if Malaysia is placed at the "top third of the countries in international assessments such as ... TIMSS in [the next] 15 years [from 2013]" (Ministry of Education, 2012, p. 9).

A review of the literature points to several factors that contributed to the poor science performance in TIMSS among Malaysian students, such as the inferiority of science teaching (Azian, 2015), lack of home educational resources (Mohshein, 2012), lack of parental support, involvement, and engagement in learning activities at home (Ismail, Samsudin, Mohd Amin, Kamarudin, Mat Daud, \& Halim, 2018), and the phenomenon where science is not adequately being valued by the students (Mokshein, 2012). Another contributing factor is that there is minimal interaction between the Malaysian science teachers and their students. This happens because teachers mainly give "lectures" with minimal student involvement (Tay \& Saleh, 2019). This supports the previous research outcomes which point to the prevalent practice of one-way communication among
Malaysian teachers (Saleh \& Aziz, 2012; Saleh $\&$ Yakob, 2014) and that the predominant activities carried out in the classrooms were mainly lecture-based (Saleh \& Yakob, 2014) with students passively listen and respond to the questions posed by their teachers in-group rather than giving a show of hands to be called upon for responses (Saleh \& Liew, 2018). Previous findings by Ong \& Ruthven (2010) also indicate a similar prevailing phenomenon in science classrooms in which the prevalent practices were characterized by direct instruction and notecopying syndrome.

The Malaysian science curriculum guides and syllabuses for all the grades in the primary, as well as the secondary schools (CDC, 2015, 2016a, 2016b, 2017), clearly indicate strong advocacy for using inquiry learning. For instance, a special theme on "Inquiry Learning" has been specifically devoted to the science syllabus for Year 3 (CDC, 2017, pp. 37-52). Why the hype for using inquiry learning? The hype for using inquiry learning in science could be plausibly attributed to the research-based benefits deriving from its use. For instance, it has been shown that using inquiry learning promotes better thinking among students, moving their thought processes beyond just memorizing science facts which are easily forgotten to that of thinking about what the students could do with the facts (Earp, 2019) Such kind of thinking has been labelled by Madhuri, Kantamreddi, \& Goteti (2012) as the higher-order thinking skills or HOTS. HOTS, as succinctly stated in the preface of the syllabuses. HOTS are indeed among the $21^{\text {st }}$ Century skills which teachers need to promote to their students. For example, "In ensuring the success of the Primary School Standard Curriculum, the teaching and learning of teachers should emphasize Higher Order Thinking Skills by focusing on the Inquiry-based Learning approach ... so that students could master the 
skills needed for the $21^{\text {st }}$ century" (CDC, 2017, p. ix). The emphasis on the use of inquiry science teaching is in step with the current pedagogical trend and direction of science education in other developed nations such as France, Denmark, the United Kingdom, and the European Union (Harlen, 2012).

\section{Problem Statement and Research Question}

The conceptual understanding of inquiry learning is still hazy and nebulous. Nebulous because not only does the concept of inquiry has different conceptualizations and interpretations, it is also being pedagogically enacted in a differing fashion, depending on one's school of thoughts (Barrow, 2006). According to Settlage (2003), "one of the most confounding terms within science education" (p. 34) is inquiry. The view by Settlage (2003) is supported by Gautreau \& Binns (2012) who opine that many science teachers are rather hazy about the what, the why, and the how of inquiry learning. The confusion over the what, the why, and the how of inquiry signifies a pedagogical glitch in implementing inquiry learning in the classrooms among the science teachers. Meanwhile, there is another fraction of teachers who, despite the directive from the Ministry of Education to employ inquiry-based science teaching, continue with the passive and teacher-centred way of teaching science (Kazempour \& Amirshokoohi, 2014; Lee, 1992; Zainal, 1988).

Given these problematic situations, there is a need to provide teachers with the researchbased classroom-validated examples of how science can be taught in an inquiry manner. With the advocacy for the use of inquiry science, teachers need a guide, reference, or even a module which provides a piece of practical and pedagogical information as to "what inquiry [learning] is, how to implement it, and how well it works" (Gautreau \& Binns, 2012, p.169). Therefore, establishing the effect of an inquiry learning model, namely the 5E Inquiry Learning Model is the main aim of this research, and that the students' achievement in the learning of science is the dependent variable. In short, this study aims to illuminate the research question: What is the comparative effect of using the 5E Inquiry Learning Model as compared to the traditional learning method on the Year 5 students' science achievement in the learning of electricity? A corollary, this study examines the null research hypothesis: There is no statistically significant difference in the Year 5 students' science achievement in the learning of electricity between those who were taught with the 5E Inquiry Learning Model and those who were taught with the teacher-centred traditional method.

The content of electricity was chosen as the context used in this study given that while electricity is a topic included in the primary and secondary curricula, many students are still having problems, misconceptions, and misunderstandings on electricity (Goris, 2016). Therefore, it is beneficial to the students if the use of the topic on electricity could subsequently provide a good grounding on the concept at hand when they move higher up in their level of education.

\section{A Review of 5E Inquiry Learning Model}

Historically, the inquiry-based learning was propounded by Gagne (1963) in his seminal paper when he proposes that the main goal science education should embrace three subgoals: ensuring that students acquire the attitudes, methods, and the understanding of inquiry. Gagne (1963) maintains that students should be able to inquire similarly as the scientists do, and this includes the fundamental capabilities such as observing, inferring, predicting, classifying, interpreting data, hypothesizing and experimenting. By having these capabilities, only then can the students understand science (Gagne, 1963).

Sharing a similar view to that of Gagne's (1963), Schwab (1966) proposes that how science is taught should parallel to how science operates and encourages the insistent use of science laboratory in assisting students to learn. Hence, the use of inquiry science teaching methodologies became the prominent theme from the many papers written by Gagne (1963) and Schwab (1960, 1966). Additionally, the use of inquiry learning has also been a resounding advocated pedagogical advocacy by the National Research Council (NRC, 1996) which produced the National Science Education Standards, and by Rutherford \& Alhgren (1989) who published the document Project 2061: Science for All Americans that was conceptualized by the American Association for the Advancement 
in Science (AAAS).

Given that the 5E Inquiry Learning Model is the instructional method employed in this study, a review of what it is and its effectiveness on student achievement will then be discussed in this section. Conceptualized by Bybee \& Landes (1990), the 5E Inquiry Learning Model entails five phases. The engagement phase provides activities that may arouse students' curiosity and elicit their pre-instructional views. The exploration phase, meanwhile, allows the students' pre-instructional views to be tested. Based on their exploration in the second phase, students develop a plausible explanation for the phenomenon, with guidance from the teachers. The elaboration phase provides extension activities that enable students to reinforce and use the new knowledge acquired. Finally, students' learning is gauged in the evaluation phase. Table 2 depicts the overview of the phases in the $5 \mathrm{E}$ Inquiry Learning Model and their corresponding pedagogical functions.
The first three phases in the 5E Inquiry Learning Model -- engagement, exploration and the explanation - are premised on the learning theory of cognitive constructivism advocated by Piaget (2000). In essence, the theory of cognitive constructivism advocates that a student's knowledge is reckoned to be constructed by either assimilation or accommodation (Agarkar, 2019). In the engagement phase, the students' pre-existing or pre-instructional views are deliberately uncovered which shows that their heads are not empty vessels waiting to be filled. Then, the students' have the opportunity to test their initial ideas by means of an investigative work provided in the exploration phase. The earlier predictions, if proven correct in the investigative work, is akin to the notion of assimilation where the initial idea or knowledge is easily associated with the existing schema. However, if the initial idea is proven incorrect and does not match the existing schema, then it must be modified through the notion of what

\section{Table 2. 5E Inquiry Learning Model: An Overview}

\begin{tabular}{ll}
\hline Phase & Pedagogical Function \\
\hline Engagement & $\begin{array}{l}\text { The engagement phase aims to encourage students' curiosity and draw out students' } \\
\text { prior knowledge, so that they are engaged in, and thinking about, the new concept } \\
\text { by providing them with short activities. These activities assist in making connections } \\
\text { between the previous and present experiences of learning, eliciting pre-instructional } \\
\text { understanding, and organizing students' post-instructional understanding. }\end{array}$ \\
Exploration & $\begin{array}{l}\text { The exploration phase provides similar or common activities or experiences to the } \\
\text { students so that conceptual change could be facilitated in which students' current or } \\
\text { pre-instructional understanding and skills are meaningfully restructured. Students }\end{array}$ \\
& may conduct lab activities making use of pre-instructional understanding or views \\
& to explore questions, hunches, predictions, hypotheses by conducting a scientific \\
investigation. & \\
The explanation phase capitalizes on the activities carried out during the engagement \\
and exploration phases in developing a restructured view. Additionally, students \\
are allowed to demonstrate their restructured views or understanding and acquired \\
scientific skills. Besides, teachers may also directly introduce a concept or skill. A \\
teacher's explanation or the explanation given in the textbooks or curriculum should \\
guide students towards a better and meaningful understanding. \\
This phase is characterized by the applications and extension of the concepts learned \\
and skills acquired through conducting new, novel, or additional activities. Essentially, \\
the elaboration phase provides activities for students to apply, develop, extend, or \\
reinforce the newly constructed knowledge and acquired skills. \\
This stage assesses students' understanding and acquired skills. It also provides \\
teachers with the opportunity to evaluate the learning, mastery, or the achievement \\
of the learning standards.
\end{tabular}


Piaget (2000) termed it as accommodation. Based on their hands-on experiences in the exploration phase, the students eventually develop a reasonable and credible explanation for the phenomenon at hand, with guidance from the teachers.

Wilson, Taylor, Kowalski, \& Carlson (2010) conducted an experimental study to gauge the effect of the 5E Inquiry Learning Model, with the science achievement used as the dependent variable. There were 58 students aged 14-16 years old who participated in the study and they were assigned randomly into either the control or the experimental group. The same teacher taught both groups to achieve similar learning objectives. The 5E Inquiry Learning Model was applied to the experimental group, while the common-place teacher-centred teaching strategies were applied to the control group. The findings indicate that the experimental group performed significantly better than the control group.

Meanwhile, using a quasi-experimental study over a 7-week duration using 60 first-year pre-service science teachers in a university (i.e., 30 each in experimental and control groups), Açışli, Yalçın, \& Turgut (2011) determined the effect of using student guiding materials on "Movement and Force" employing the 5E Inquiry Learning Model. The science achievement used as the dependent variable. Analysed using the independent samples t-test, the findings indicated that the experimental performed significantly better than the control group that utilized the traditional method.

Hokkanen (2011), in her master's thesis, ascertained the effect on student science achievement deriving from using the $5 \mathrm{E}$ Inquiry Learning model, as compared to the commonplace method. There were 96, 98, and $1147^{\text {th }}$ grade students who responded to the pre- and posttest for the learning of atoms, force and motion, velocity, and acceleration. After the 3-week experimental duration, science achievement was measured by means of a 57item Illinois State Achievement Test (ISAT). The findings indicated that upon averaging the percentage of improvement for each question, greater gains were noted by the students in the experimental group.

In another study, Abdi (2014) also determined the effect on the science achievement of $5^{\text {th }}$-grade female students at Kermanshah, Iran deriving from using the $5 \mathrm{E}$ Inquiry Learning Model. A pre-posttest quasi-experimental study was utilized. Over an 8-week intervention period, the same teacher instructed the experimental group $(n=20)$ "with inquiry-based instruction supported 5E learning cycle" (Abdi, 2014, p. $39)$, and the control group $(n=20)$ with the traditional method. Analysed using the analysis of covariance (ANCOVA), the experimental performed significantly better than the control group that utilized the traditional method.

Sen \& Oskay (2017) determined the effect on the undergraduate students' achievement in Chemical Equilibrium deriving from using the 5E Inquiry Learning. Utilizing a quasiexperimental design with the voluntary participation of 34 Turkish undergraduates (i.e., 8 males and 26 females), and equally, utilizing a similar textbook, the same teacher taught both the experimental group $(n=18)$ and the control group $(n=16)$. The pre-test and the posttest were measured using the Chemical Equilibrium Concept Test (CECT). Analysed by means of an independent samples t-test, it was found that the undergraduates in the experimental group performed significantly better than their counterparts in the control group.

In summary, the 5E Inquiry Learning Model was investigated at the primary level (Abdi, 2014), the secondary level (Hokkanen, 2011; Wilson et al., 2010), and the undergraduate level (Açışlı et al., 2011; Sen \& Oskay, 2017) to determine its effectiveness. However, Veloo, Perumal, \& Vikneswary (2013) recommended that the experimental investigation of the $5 \mathrm{E}$ Inquiry Learning, particularly on its effectiveness in the teaching of science within the Malaysian context needs to be conducted more widely and frequently given its scarcity and infrequent conduct of such kind of experimental studies.

\section{METHODOLOGY}

Based on the research question, a quasiexperimental design that entails the use of a pretest-posttest and a control group (Cohen, Manion, \& Morrison, 2017) was deemed appropriate. Students from two intact classes consisting of 33 and 32 11-year-old students (i.e., Year 5) respectively participated in the study. These are Malay students from a national primary school located in an urban area in 
Malaysia. Using randomization, the two intact classes were randomly assigned to either the experimental or the control group. The use of the existing intact classes was aimed at maintaining the ecosystem of the school. The same teacher (i.e., the second author) taught both groups. Table 3 summarizes the number of students by group and gender.

A week before the commencement of the two periods of thirty-minute intervention, the pretest was administered. Then, using the topic on electricity as the learning context where its main learning objectives were to differentiate the brightness of the bulbs in a complete circuit by changing either the number of bulbs or the number of batteries, and to compare the brightness of bulbs between the serial and parallel circuits. The experimental group was taught using the 5E Inquiry Learning Model that entails student prediction (Engagement Phase) on the comparative brightness when given a number of diagrams with differing number of bulbs or batteries in a serial circuit and in a parallel circuit. The students were then given the opportunity to test their prediction (Exploration Phase) and subsequently, they were facilitated into concluding that the number of bulbs and the number of batteries are the factors that influence the brightness of an electric circuit, and that the bulbs which are arranged in a parallel circuit will light up brighter as compared to the equal number of bulbs that are arranged in a serial circuit when both circuits are complete with their switches on. The reason behind the difference in brightness of the two circuits in terms of electrical energy flow were interactively discussed (Explanation Phase). The knowledge acquired by the students were then consolidated by giving them further exercises on electric circuits in a worksheet (Expansion Phase). Finally, an evaluation sheet was given to gauge the extent to which the students have mastered the learning objectives (Evaluation Phase).

Meanwhile, in the control group, students were taught the learning objectives through the teacher-centred traditional teaching which was characterised by the didactic presentation of the teacher on the learning objectives and the confirmatory activities of students that ensued after the teacher presentation. Finally, pertinent exercises were given to the students.

The posttest, which is similar to the pretest except that they were slightly rearranged, was administered a day after the intervention. In the pretest and the posttest, there were 20 multiple-choice items and 34 structured items. Each multiple-choice item consists of one correct response and three distractors, while each the fill-in-the-black items requires one correct response. As such, all these items are scored dichotomously, either correct or incorrect. The items were developed based on a test specification table, covering the pertinent learning standards on the topic of electricity in Unit 7 of Year 5 Science as stipulated in the Primary Science Curriculum Standard (CDC, 2016b). To enhance the content validity, the test items were examined by two expert teachers in science. The 54-item test has sufficient internal consistency reliability measured by KR20 with a value of .84 (de Vaus, 2001; Nunnally, 1978). For ethical purposes, written permission was sought from the headmaster of the participating school. Upon the receipt of a favourable response from the headmaster, only then the research commenced.

In this study, the independent variable refers to the method of teaching, namely the $5 \mathrm{E}$ Inquiry Learning Model versus the conventional teacher-centred instruction. Meanwhile, the dependent variable which constitutes the treatment effect refers to the science achievement that was measured by means of the posttest. The pretest was used as a covariate in the analysis of the data using the analysis of variance (ANCOVA). A covariate, according to VandenBos (2007), is a variable that exhibits covariation with the dependent variable and thus, it is used in ANCOVA to statistically adjust the groups so that they are equivalent.

Table 3. Number of Students by Group and Gender

\begin{tabular}{|c|c|c|c|c|}
\hline & & \multicolumn{2}{|c|}{ Gender } & \multirow{2}{*}{ Total } \\
\hline & & Male & Female & \\
\hline \multirow{2}{*}{ Group } & Control & 16 & 16 & 32 \\
\hline & Experiment & 13 & 20 & 33 \\
\hline Total & & 29 & 36 & 65 \\
\hline
\end{tabular}




\section{FINDINGS}

As shown in Table 4, the analysis of pretest data for electricity indicates a significant difference between the pretest means of the experimental group $(M=35.58, S D=14.57)$ and the control group $(M=43.98, S D=16.93)$; $t(63)=2.15, p=.04<.05$. This significant difference implies a non-equivalence of the two groups before the intervention. Therefore, the posttest data should then be analysed using the analysis of covariance (ANCOVA). According to Karpman (1983), when there is a pretest difference, ANCOVA should be used to measure a treatment effect (e.g., the effect of 5E Inquiry Learning) on a criterion measure (e.g., science achievement in electricity) after adjusting for initial difference on the covariate (e.g., pretest).

However, before performing the ANCOVA, the assumption for homogeneity of the regression slope was conducted to "look at the overall relationship between the outcome (dependent variable) and the covariate: we fit a regression line to the entire set of data, ignoring to which group a person belongs. In fitting this overall model, we, therefore, assume that this overall relationship is true for all groups of participants" (Field, 2009, p. 399). If the assumption is violated or not met, then the ANVOCA should not be performed.

Table 5 shows that the two-way factor and covariate interaction is statistically significant $\left(F_{(1,62)}=11.29, p=.001<.05\right)$. This result indicates that there is a failure to meet the assumption of homogeneity of the regression slope. Hence, ANCOVA should not be performed.

Therefore, when the assumption is violated, Grace-Martin (n.d.) recommends an option to categorize the covariate and analyse the treatment effect on the posttest by each category of the covariate. In categorizing the pretest, two categories were chosen due to the sample size. Given that the pretest data range from 11.11 to 77.78 (i.e., a class interval of approximately 67), then each group should have an approximate class interval of 34 . Therefore, the pretest scores for the first category range from below 44 (i.e., minimum +34$)$, while the pretest scores for the second category range from 44 and above.

Table 4. The Independent Samples $t$-test Result for Electricity Pretest

\begin{tabular}{|c|c|c|c|c|c|c|c|c|}
\hline \multirow{2}{*}{ Variable } & \multicolumn{3}{|c|}{ Experimental } & \multicolumn{3}{|c|}{ Control } & \multirow{2}{*}{$t$} & \multirow{2}{*}{$p$} \\
\hline & $N$ & Mean & $S D$ & $N$ & Mean & $S D$ & & \\
\hline Pretest & 33 & 35.58 & 14.57 & 32 & 43.98 & 16.93 & 2.15 & .04 \\
\hline
\end{tabular}

Table 5. Results from the Testing of the Assumption for Homogeneity of the Regression Slope

\begin{tabular}{lccccc}
\hline Source & $\begin{array}{c}\text { Type III Sum of } \\
\text { Squares }\end{array}$ & $\boldsymbol{d f}$ & Mean Square & $\boldsymbol{F}$ & Sig. \\
\hline Corrected model & $18102.74^{\mathrm{a}}$ & 3 & 6034.25 & 30.37 & .000 \\
Intercept & 30832.49 & 1 & 30832.49 & 155.18 & .000 \\
Group & 8326.18 & 1 & 8326.18 & 41.91 & .000 \\
Pre-electric & 382.66 & 1 & 382.66 & 1.93 & .170 \\
Group * Pre-electric & 2243.78 & 1 & 2243.78 & 11.29 & .001 \\
Error & 12120.22 & 61 & 198.69 & & \\
Total & 330833.33 & 65 & & & \\
Corrected total & 30222.96 & 64 & & & \\
\hline
\end{tabular}

Note: a. $R$ Squared $=.599($ Adjusted $R$ Squared $=.579)$ 
As shown in Table 6, the analysis of twocategory pretest data for electricity indicates that for the low achieving students (i.e., first category with pretest scores less than 44), there was no significant difference in the pretest means between the experimental group $(M=28.70, S D$ $=8.84)$ and the control group $(M=25.15, S D$ $=12.17) ; t(34)=1.00, p=.324>.05$. Equally, for the average achieving students (i.e., second category of pretest scores than range from 44 and above), there was no significant difference between the pretest means for the experimental group $(M=53.91, S D=10.25)$ and the control group $(M=55.28, S D=4.89) ; t(27)=.49, p=$ $.626>.05$. These results imply an equivalence of the experimental and control groups across the low and average achieving students before the intervention in terms of science achievement on the topic of electricity. Hence, the independent samples $t$-test could be performed on the posttest data.

Table 7 summarises the results of the analyses of posttest data using the independent samples $t$-test by pretest category. It was found that there was a significant difference in the posttest means between the experimental group $(M=83.56, S D=15.46)$ and the control group $(M=42.13, S D=18.47) ; t(34)=7.11, p<.001$ among the low achieving students. Equally, there was a significant difference in the posttest means between the experimental group $(M=81.69, S D$ $=15.26)$ and the control group $(M=58.70, S D=$ 9.87); $t(27)=4.88, p<.001$ among the average achieving students.
Given that the experimental group performed significantly better than the control group across all categories of students, the null hypothesis in that "there is no significant difference in the science achievement in the learning of electricity between the experimental group that was taught using 5E Inquiry Learning Model and the control group that was taught using the teacher-centred traditional teaching method among the Year 3 primary school students" was not accepted. This also suggests that a significant outcome occurred as a result of the intervention.

\section{DISCUSSION}

This study aimed at gauging the comparative effect of employing the 5E Inquiry Learning Model as opposed to the use of the traditional teaching method on the Year 5 students' science achievement in electricity. The main finding indicates the superiority of the $5 \mathrm{E}$ Inquiry Learning Model over the traditional teaching method. This finding is consonant to the findings of Abdi (2014), Açışli et al. (2011), Hokkanen (2011), Sen \& Oskay (2017), and Wilson et al. (2010) in terms of the effect of $5 \mathrm{E}$ Inquiry Learning method, although these studies differ in terms of the topics employed as the context, measures employed to gauge the science achievement, and the educational level of the participants involved.

The exploration phase of the $5 \mathrm{E}$ Inquiry Learning Model entails science practical and hands-on activities where students test their

Table 6. Results of the Independent Samples $t$-tests for Electricity Pretest Data by Pretest Category

\begin{tabular}{|c|c|c|c|c|c|c|c|c|}
\hline \multirow{2}{*}{ Pretest Category } & \multicolumn{3}{|c|}{ Experimental } & \multicolumn{3}{|c|}{ Control } & \multirow{2}{*}{$t$} & \multirow{2}{*}{$p$} \\
\hline & $N$ & Mean & $S D$ & $N$ & Mean & $S D$ & & \\
\hline Low & 24 & 28.70 & 8.84 & 12 & 25.15 & 12.17 & 1.00 & .324 \\
\hline Average & 9 & 53.91 & 10.25 & 20 & 55.28 & 4.89 & .49 & .626 \\
\hline
\end{tabular}

Table 7. Results of Independent Samples $t$-tests for Electricity Posttest Data by Initial Achievement

\begin{tabular}{|c|c|c|c|c|c|c|c|c|}
\hline \multirow{2}{*}{ Initial Achievement } & \multicolumn{3}{|c|}{ Experimental } & \multicolumn{3}{|c|}{ Control } & \multirow{2}{*}{$t$} & \multirow{2}{*}{$p$} \\
\hline & $N$ & Mean & $S D$ & $N$ & Mean & $S D$ & & \\
\hline Low & 24 & 83.56 & 15.46 & 12 & 42.13 & 18.47 & 7.11 & $.000^{*}$ \\
\hline Average & 9 & 81.69 & 15.26 & 20 & 58.70 & 9.87 & 4.88 & $.000^{*}$ \\
\hline
\end{tabular}

*significant at $p<.001$ 
earlier predictions were supported or otherwise. The students had the opportunity to explore by utilizing practical work and hands-on activities, and such a learning approach is akin to what Alkhateeb \& Milhem (2020) referred to as placing the students "at the heart of the learning process" (p. 620). A plethora of research has pointed to the fact that student investigative work and hands-on activities are academically and practically beneficial (Jaakkola \& Nurmi, 2008; Klahr, Triona, \& Williams, 2007). By extrapolation, the finding of this research which capitalizes on practical works and hands-on activities corroborates the positive impact of investigative work and hands-on activities on the variable of student science achievement.

Based on the works by Barrow (2006), Gautreau \& Binns (2012), and Settlage (2003), an emerging but worrying phenomenon was identified in which a large proportion of science teachers are still confused, puzzled, and unclear of the notion on inquiry, both conceptually and pedagogically. Therefore, science teachers encounter difficulties in integrating inquiry learning in their lesson planning and classroom instruction (Crawford, 2007). Therefore, it is pertinent to ensure that science teachers understand the notion and practice of inquiry within the same frequency (Barrow, 2006) and as such, the existing pre-service science education programs should be revisited, reviewed, and reorganized. Additionally, the mechanism in supporting science teachers via inquiry learning workshops should be in place (Akerson, Hanson, \& Cullen, 2007; Akerson \& Hanuscin, 2007; Barrow, 2006; Silm, Tiitsaar, Pedaste, Zacharia, \& Papaevripidou, 2017; Zohar, 2007).

On the in-service professional development workshops on inquiry-based learning, science teachers should be familiarised with research-validated models on inquiry learning, such as the 5E Inquiry Learning Model (Ong et al., 2020). The familiarisation sessions should be simulatively hands-on, instead of lecture-based. Simulative in the sense that when introducing a particular teaching model, the phases in that model are thoughtfully carried out or "simulated" whereby the facilitator (or trainer) acts as a teacher while the participants act as students, and a suitable science concept is used as the context in the simulation (Ong et al., 2020). The teachers, who had simulated through the phases in the model, will make sense and comprehend because they have personally experience the learning using the particular teaching model. Upon getting a firm foundation and understanding of the model, only then opportunities are provided for the science teachers in developing some lesson ideas around the learning standards within certain topics using the particular teaching model, be it 5E Inquiry Learning Model, or other science teaching models and approaches.

\section{CONCLUSION}

This study concludes that the use of the $5 \mathrm{E}$ Inquiry Learning Model is indeed beneficial and successful in enhancing science achievement. That is to say, if teachers want to enhance students' achievement in science, they should be employing the 5E Inquiry Learning Model in their science classrooms instead of using the common-place traditional method. Given these educational benefits and positive impact, inquiry learning through the use of the 5E Inquiry Learning Model should be a dominant science teaching strategy in the Malaysian science classrooms.

\section{ACKNOWLEDGMENT}

This research has been carried out under the Fundamental Research Grants Scheme 20190029-107-02 (FRGS/1/2018/SSI09/UPSI/01/3) provided by the Ministry of Education of Malaysia. The authors would like to extend their gratitude to Universiti Pendidikan Sultan Idris (UPSI) that helped manage the grants.

\section{REFERENCES}

Abdi, A. (2014). The effect of inquiry-based learning method on students' academic achievement in a science course. Universal Journal of Educational Research, 2(1), 37-41. https://www.hrpub.org/journals/ article info.php?aid=944.

Açışl1, S., Yalçın, S. A., \& Turgut, U. (2011). Effects of the 5E learning model on students' academic achievements in movement and force issues. Procedia Social and Behavioral Sciences, 15, 2459-2462. https://doi.org/10.1016/j. sbspro.2011.04.128.

Agarkar, S. C. (2019). Influence of learning 
theories on science education. Resonance, 24(8), 847-859. https://doi.org/10.1007/ s12045-019-0848-7.

Akerson, V. L., Hanson, D. L., \& Cullen, T. A. (2007). The influence of guided inquiry and explicit instruction on K-6 teachers' views of nature of science. Journal of Science Teacher Education, 18(5), 751772. https://doi.org/10.1007/s10972-0079065-4.

Akerson, V. L., \& Hanuscin, D. L. (2007). Teaching nature of science through inquiry: The results of a 3-year professional development program. Journal of Research in Science Teaching, 44(5), 653-680. https://doi.org/10.1002/ tea.20159.

Alcácer, V., \& Cruz-Machado, V. (2019). Scanning the Industry 4.0: A literature review on technologies for manufacturing systems. Engineering Science and Technology, an International Journal, 22(3), 899-919. https://doi.org/10.1016/j. jestch.2019.01.006.

Alkhateeb, M. A., \& Milhem, O. A. Q. B (2020). Student's concepts of and approaches to learning and the relationships between them. Cakrawala Pendidikan, 39(3), 620-632. https://doi.org/10.21831/ cp.v39i3.33277.

Azian, T. S. A. (2015, 26-27 May). STEM Education: Policies and prospects towards achieving international standards and meeting national development needs. Paper presented at International Science, Technology, Engineering and Mathematics High-Level Policy Forum on Evidence-Based Science Education in Developing Countries, Kuala Lumpur, Malaysia.

Barrow, L. H. (2006). A brief history of inquiry: From Dewey to standards. Journal of Science Teacher Education, 17(3), 265278. https://doi.org/10.1007/s10972-0069008-5.

Bybee, R. W., \& Landes, N. M. (1990). Science for life and living: An elementary school science program from Biological Sciences Improvement Study (BSCS). The American Biology Teacher, 52(2), 92-98. https://doi.org/10.2307/4449042.

Cohen, L., Manion, L., \& Morrison, K. (2017). Research methods in education $\left(8^{\text {th }} \mathrm{ed}\right)$. New York, NY: Routledge.

Crawford, B. A. (2007). Learning to teach science as inquiry in the rough and tumble of practice. Journal of Research in Science Teaching, 44(4), 613-642. https:// doi.org/10.1002/tea.20157.

CDC (Curriculum Development Division). (2015). Kurikulum standard sekolah rendah Sains Tahun 1: Dokumen standard kurikulum dan pentaksiran. Putrajaya, Malaysia: Ministry of Education Malaysia.

CDC (Curriculum Development Division). (2016a). Kurikulum standard sekolah rendah Sains Tahun 2: Dokumen standard kurikulum dan pentaksiran. Putrajaya, Malaysia: Ministry of Education Malaysia.

CDC (Curriculum Development Division). (2016b). Kurikulum standard sekolah rendah Sains Tahun 5: Dokumen standard kurikulum dan pentaksiran. Putrajaya, Malaysia: Ministry of Education Malaysia.

CDC (Curriculum Development Division). (2017). Kurikulum standard sekolah rendah Sains Tahun 3: Dokumen standard kurikulum dan pentaksiran. Putrajaya, Malaysia: Ministry of Education Malaysia.

De Vaus, D. A. (2001). Research design in social research. London: SAGE.

Earp, J. (2019, 2 December). Developing higherorder thinking skills. Teacher. https:// www.teachermagazine.com.au/articles/ developing-higher-order-thinking-skills.

Field, A. (2009) Discovering statistics using SPSS ( $3^{\text {rd }}$ ed) London: Sage Publications Ltd.

Gagne, R. M. (1963). The learning requirements for inquiry. Journal of Research in Science Teaching, 1(2), 144-153. https://doi.org/10.1002/tea.3660010211. 
Gautreau, B. T., \& Binns, I. C. (2012). Investigating student attitudes and achievements in an environmental placebased inquiry in secondary classrooms. International Journal of Environmental \& Science Education, 7(2), 167-195. https:// files.eric.ed.gov/fulltext/EJ990515.pdf.

Grace-Martin, K. (n. d.). When assumptions of ANCOVA are irrelevant. https://www. theanalysisfactor.com/assumptions-ofancova/.

Goris, T. V. (2016). Common misunderstandings of electricity: Analysis of interviewresponses of electrical engineering technology students. International Journal of Engineering Pedagogy, 6(1), 4-10. https://online-journals.org/index. php/i-jep/article/view/5146.

Harlen, W. (2012). Inquiry in science education. Montrouge, France: Foundation La main à la pâte.

Hokkanen, S. L. (2011). Improving student achievement, interest and confidence in science through the implementation of the 5e learning cycle in the middle grades of an urban school (Masters thesis, Montana State University). https://scholarworks. montana.edu/xmlui/handle/1/1487.

Ismail, M. E., Samsudin, M. A., Mohd Amin, N. F., Kamarudin, N., Mat Daud, K. A., \& Halim, L. (2018). Contributing factors to science achievement in TIMSS Malaysia: Direct model and indirect model. International Journal of Engineering \& Technology, 7(4.30), 423-428. https://doi. org/10.14419/ijet.v7i4.30.22354.

Jaakkola, T., \& Nurmi, S. (2008). Fostering elementary school students' understanding of simple electricity by combining simulation and laboratory activities. Journal of Computer Assisted Learning, 24(4), 271-283. https://doi.org/10.1111/ j.1365-2729.2007.00259.x.

Kamaludin, A. A. (2019, 11 October). New vision to lift Malaysia to developed nation status. BERNAMA. https://www.bernama. com/en/features/news.php?id=1774763.
Karpman, M. B. (1983). The JohnsonNeyman technique using SPSS or BMDP. Educational and Psychological Measurement, 43(1), 137-147. https://doi. org $/ 10.1177 / 001316448304300117$.

Kazempour, M., \& Amirshokoohi, A. (2014). Transitioning to inquiry-based teaching: Exploring science teachers' professional development experiences. International Journal of Environmental \& Science Education, 9(3), 285-309. https://pennstate.pure.elsevier.com/en/ publications/transitioning-to-inquirybased-teaching-exploring-scienceteacher.

Klahr, D., Triona, L. M., \& Williams, C. (2007). Hands-on what? The relative effectiveness of physical versus virtual materials in an engineering design project by middle school children. Journal of Research in Science Teaching, 44(1), 183-203. https:// doi.org/10.1002/tea.20152.

Lee, M. N. N. (1992). School science curriculum reforms in Malaysia: World influences and national context. International Journal of ScienceEducation, 14(3),249-263.https:// doi.org/10.1080/0950069920140302.

Madhuri, G. V., Kantamreddi, V. S. S. N., \& Goteti, L. N. S. P. (2012). Promoting higher-order thinking skills using inquirybased learning. European Journal of Engineering Education, 37(2), 117-123. https://doi.org/10.1080/03043797.2012.6 $\underline{61701 .}$

Martin, M. O., Mullis, I. V. S., Foy, P., \& Stanco, G. M. (2012). The TIMSS 2011 international results in Science. Chestnut Hill, MA: TIMSS \& PIRLS International Study Center, Boston College.

Martin, M. O., Mullis, I. V. S., Goy, P., \& Hooper, M. (2016). TIMSS 2015 international results in Science. Boston, MA: The International Association for the Evaluation of Educational Achievement (IEA).

Ministry of Education. (2012). Malaysia education blueprint 2013-2025 (Preschool 
to post-secondary education). Putrajaya, Malaysia: Author.

Mokshein, S. E. (2012). Predictors of science achievement among the lower-secondary school students in Malaysia: An analysis of TIMSS data. Jurnal Pendidikan Sains dan Matematik Malaysia, 3(1), 2547. https://ejournal.upsi.edu.my/index. php/JPSMM/article/view/2108.

NRC (National Research Council). (1996). The national Science education standards. Washington, DC: National Academy Press.

Nunnally, J. C. (1978). Psychometric theory $\left(2^{\text {nd }}\right.$ ed). New York, NY: McGraw Hill.

Ong, E. T., \& Ruthven, K. (2010). The distinctiveness and effectiveness of science teaching in the Malaysian 'Smart School'. Research in Science and Technological Education, 28(1), 25-41. https://doi. org/10.1080/02635140903513557.

Ong, E. T., Luo, X., Yuan, J., \& Yingprayoon, J. (2020). The Effectiveness of Professional development programme on the use of STEM-based 5E inquiry learning model for science teachers in China. Science Education International, 31(2), 179-184. https://doi.org/10.33828/sei.v31.i2.7.

Piaget, J. (2000). The psychology of the child. London: Basic Books.

Rutherford, F. J., \& Ahlgren, A. (1989). Science for all Americans. New York, NY: Oxford.

Saleh, S., \& Aziz, A. (2012, 28-29 September). Teaching practices among secondary school teachers in Malaysia. Paper presented at $20122^{\text {nd }}$ International Conference on Education, Research and Innovation, Phnom Penh, Cambodia. http://www.ipedr.com/vol47/014ICERI2012-S00023.pdf.

Saleh, S., \& Liew, S. S. (2018). Classroom pedagogy in German and Malaysian secondary school: A comparative study. Asia Pacific Journal of Educators and Education, 33(1), 57-73. https://doi.
org/10.21315/APJEE2018.33.5.

Saleh, S., \& Yakob, N. (2014). Teachers' conceptions about physics instruction: A case study in Malaysian schools. Australian Journal of Basic and Applied Sciences, 8(24), 340-347. http://www. ajbasweb.com/old/ajbas/2014/IPN\%20 JAKARTA/340-347.pdf.

Sen, S., \& Oskay, O. O. (2017). The effects of 5E inquiry learning activities on achievement and attitude toward Chemistry. Journal of Education and Learning, 6(1), 1-9. https://doi.org/10.5539/jel.v6n1p1.

Schwab, J. (1960). Enquiry, the science teacher, and the educator. The School Review, 68(2), 176-195. https://www.jstor.org/ stable/1083585.

Schwab, J. (1966). The teaching of science. Cambridge, MA: Harvard University Press.

Settlage, J. (2003, January). Inquiry's allure and illusion: Why it remains just beyond our reach. Paper presented at the annual meeting of the National Association for Research in Science Teaching, Philadelphia, PA.

Silm, G., Tiitsaar, K., Pedaste, M., Zacharia, Z. C., \& Papaevripidou, M. (2017). Teachers' readiness to use inquiry-based learning: An investigation of teachers' sense of efficacy and attitudes toward inquiry-based learning. Science Education International, 28(4), 315-325. http:// www.icaseonline.net/sei/december2017/ p6.pdf.

Tay, A. J., \& Saleh, S. (2019). Science teachers' instructional practices in Malaysian and German secondary schools. Journal of Education and Learning, 8(4), 124-135. https://doi.org/10.5539/jel.v8n4p124.

VandenBos, G. R.(Ed.). (2007). APA dictionary of psychology. Washington, DC: American Psychological Association.

Veloo, A., Perumal, S., \& Vikneswary, R. (2013). Inquiry-based instruction, 
students' attitudes, and teachers' support towards science achievement in rural primary schools. 3rd World Conference on Learning, Teaching, and Educational Leadership. Procedia - Social and Behavioral Sciences, 93, 65-69. https:// doi.org/10.1016/j.sbspro.2013.09.153.

Vijaindren,A. (2018, 13 August). Malaysia needs 500,000 scientists and engineers by 2020 . News Straits Times. https://www.nst. com.my/news/politics/2018/08/400909/ malaysia-needs-500000- scientists-andengineers-2020.

Wilson, C. D., Taylor, J. A., Kowalski, S. M., \& Carlson, J. (2010). The relative effects and equity of inquiry-based and commonplace science teaching on students' knowledge, reasoning, and argumentation. Journal of Research in Science Teaching, 47(3), 276301. https://doi.org/10.1002/tea.20329.

Zainal, G. (1988). Curricular decision-making in the diffusion of educational innovation in Malaysia (Doctoral Dissertation, University of Southampton). https:// ethos.bl.uk/OrderDetails.do?uin=uk. bl.ethos.237062.

Zohar, A. (2007). Science teacher education and professional development in argumentation. In S. Erduran \& M. P. Jimenez-Aleixandre (Eds.). Argumentation in science education: Perspectives from classroom-based research. Dordrecht, Netherlands: Springer, pp. 245-268. 